\begin{tabular}{|c|c|c|}
\hline Beitr. Ent. & Keltern & ISSN 0005-805X \\
\hline $52(2002) 2$ & S. 353-366 & 16.12 .2002 \\
\hline
\end{tabular}

\title{
On the larval morphology of Micropterix aruncella (SCOPOLI, 1763)
}

\section{(Lepidoptera: Micropterigidae)}

With 20 figures

\author{
BERNHARD KLAUSNITZER, ERIXIN MEYER, WOLFGANG KÖSSLER and GERHARD \\ EISENBEIS
}

\section{Summary}

Larvae and adults of Micropterix aruncella (SCOPOLI, 1763)were collected from alpine pasture land near the tree line (2000 m a.s.l., Stubai Valley, northern Tyrol, Central Alps, Austria). 158 larvae were extracted from the superficial soil using the Kempson technique (MEYER 1980) between May and October 1998.81 adults (42 males, 39 females) were collected in emergence traps between July 10 and August 23, 2001. The integument of the larvae exhibits numerous modifications such as folds, bulges, dises and conical structures. The external anatomy of the mouthparts, antennae and legs are documented by SEM micrographs and original drawings. The frequency distribution of head capsule width of the investigated larvae falls into 4 groups indicative of four instar larvae which according to a progression scale increase at each molt by a ratio of 1.2. - 1.7.

\section{Zusammenfassung}

Larven und Imagines von Micropterix aruncella (SCopor., 1763) (Lepidoptera: Micropterigidae) wurden auf Almwiesen an der Waldgrenze oberhalb des Ortes Neustift (auf $2000 \mathrm{~m}$ NN, Stubaital, Zentralalpen, Österreich) gesammelt: 158 Larven mit einem KEMPSON-Apparat extrahiert aus Bodenproben, 81 Imagines (42 Männchen, 39 Weibchen) mit Emergenzzelten zwischen dem 10. Juli und 23. August 2001. Larren der phylogenetisch besonders interessanten Gattung Micropterix HÜBNER (Antennen länger als Kopflkapsel; Kopfkapsel völlig in den Thorax einziehbar; 1.-8. Abdominalsegment mit zugespitzten Abdominalbeinen ohne Häkchen; Körper mit mehreren Reihen abgeflachter, gerippter keulenförmiger Haare; Körperquerschnitt hexagonal) wurden nur selten gefunden und untersucht. Die Larve von Micropterix antncella war bisher nahezu unbelkannt. Das Integument zeigt zahlteiche Sonderbildungen, z. B. mit modifizierten Haaren bedeckte Wülste, scheibenförmige Strukturen mit \pm wabenförtmiger Oberflächenstruktur. Die äußere Anatomie der Antennen, des Labrum, der Mandibeln, Maxillen und des Labium. sowie der Beine und Abdominalbeine wird beschrieben, mit Literaturangaben verglichen und durch REM-Aufnahmen und Originalabbildungen ebenfalls dokumentiert. Die Häufigkeitsverteilung der Kopfkapselbreiten zeigt 4 Maxima, die 4 Larvenstadien wahrscheinlich werden lassen, deren Wachstumsrate zwischen 1,2 und 1,7 liegt. Bei der Untersuchung der Larven von Micropterix aruncella wurden Unterschiede zu der Beschreibung von Micropterix caltbella durch LORENZ (1961) gefunden, die vielleicht zur Differenzierung der Larven der beiden Arten herangezogen werden können.

\section{Key words}

Lepidoptera, Micropterigidae, Micropterix aruncella, larval morphology, Central Alps, North Tyrol, alpine pasture land 


\section{Introduction}

The Micropterigidae are characterized by several presumable autapomorphies as well as some plesiomorphic features, such as the asymmetric mandibles which enable the consumption of solid foods, the absence of a sucking proboscis in the adults (also absent in Agathiphagidae and Heterobathmiidae), a "primitive" wing venation, the labium with paraglossae, the pupae developing as pupa libera with large movable mandibles, the unusually long antennae of the larvae, and the particular construction of the integument which is unique among the Arthropoda (KRISTENSEN 1999).

Although the adults of the Micropterigidae are well-studied, our knowledge of their larvae, which deviate strongly from those of other Lepidoptera, is still incomplete. Aside from the Central European genus Micropterix HÜBNER, members of other genera, such as Neomicropteryx nipponensis IsSIKI from Japan (YASUDA 1962); Sabatinca chalcophanes from New Zealand (TILlYARD 1922/1923, KRISTENSEN 1990); Epimartyria pardella (WALSINGHAM) and E auricrinella (WALSINGHAM) from North America (TUSKES \& SMITH 1984, DAVIS 1987) are generally well-documented. The larval chaetotaxy of $P a-$ ramartyria and Neomicropteryx are described by HASHIMOTO (2001).

The larvae of more than 40 European species (GAEDIKE \& HEINICKE 1999, HEATH 1996, HUEMER \& TARMANN 1993), all belonging to the single genus Micropterix HÜBNER, are only quite rarely found, and our understanding of their way of life is therefore deficient. The majority of research has been conducted on Micropterix calthella (LINNAEUS, 1761) (CHAPMAN 1894, 1916/1917, MARTYNOVA 1950, HANNEMANN 1957, LORENZ 1959, 1961, PARENTI 1965, HEATH 1976, CARTER \& DUGDALE 1982, KOZLOW 1991, HAMON \& CHAUVIN 1995). In particular, CARTER \& DUGDALE (1982) devoted attention to two other Central European species: Micropterix aruncella (SCOPOLI) and Micropterix aureatella (SCOPOLI).

Species assignment of the larvae

Relatively numerous larvae (Table 6) were discovered in the alpine meadows and pastures of the Kaserstattalm in the Stubai Valley (northern Tyrol), the conditions of the habitat were evaluated, and it is now possible to supplement our existing information on the morphology of Micropterix aruncella. The Kaserstattalm lies northwest from Neustift in the Stubai Valley $\left(11^{\circ} 17.390^{\prime} \mathrm{E}\right.$ and $47^{\circ} 07.521^{\prime} \mathrm{N}$, Gauß-Krüger coordinates: 223.382 X-axis, 221.384 $Y$ - axis).

In the 1998 field studies only larvae were found. To enable identification of the larvae, the adults were collected by emergence traps between July 10 and August 23, 2001 (MEYER et al. 2002).

\section{Description of the larvae of Micropterix aruncella}

\section{Results from examination with light-microscopy and scanning electron microscopy}

Body elongate, oval, widest in the middle (abdominal segments 2-4), tapering slightly at both ends. In cross-section, body more or less hexagonal (autapomorphy). Abdominal 
segments separated by deep grooves, which are less clear between thoracic segments. Body with longitudinal crests, that clearly cut into each segment, so that dome-like elevations occur. On both sides lies a lateral bulge, and two smaller ones ventrolaterally. Thoracic segments show only a single ventrolateral bulge.

Body (mesothorax and metathorax, abdominal segments 1-8) covered with 8 , sometimes double, longitudinal rows (dorsal, dorsolateral, lateral, ventrolateral) of variously shaped modified hairs. Hairs may be club-shaped, somewhat flattened, costate and narrowed at base (Figs 12,13). Hairs on the 8th abdominal segment thinner and longer. Hairs in last larval stage of Micropterix calthella $0.18 \mathrm{~mm}$ long (HAMON \& CHAUVIN 1995), in Micropterix aruncella, 0.09-0.10 mm. As stated by LORENZ (1961) and KOZLOW (1991) these hairs probably serve as support elements during locomotion on the ground surface and in the interstitial ground system. HAMON \& CHAUVIN (1995) however found no associated muscle fibers, so that this function appears unlikely. These authors point out differences in the shape of these hairs among the individual segments and among the larval stages and differentiate four types of construction.

Two dorsal double-rows of such club-shaped hairs present on the mesothorax and metathorax as well as on the abdominal segments 1-8. A dorsolateral double-row confined to mesothorax and metathorax with three club-shaped hairs, as well as a lateral single-row

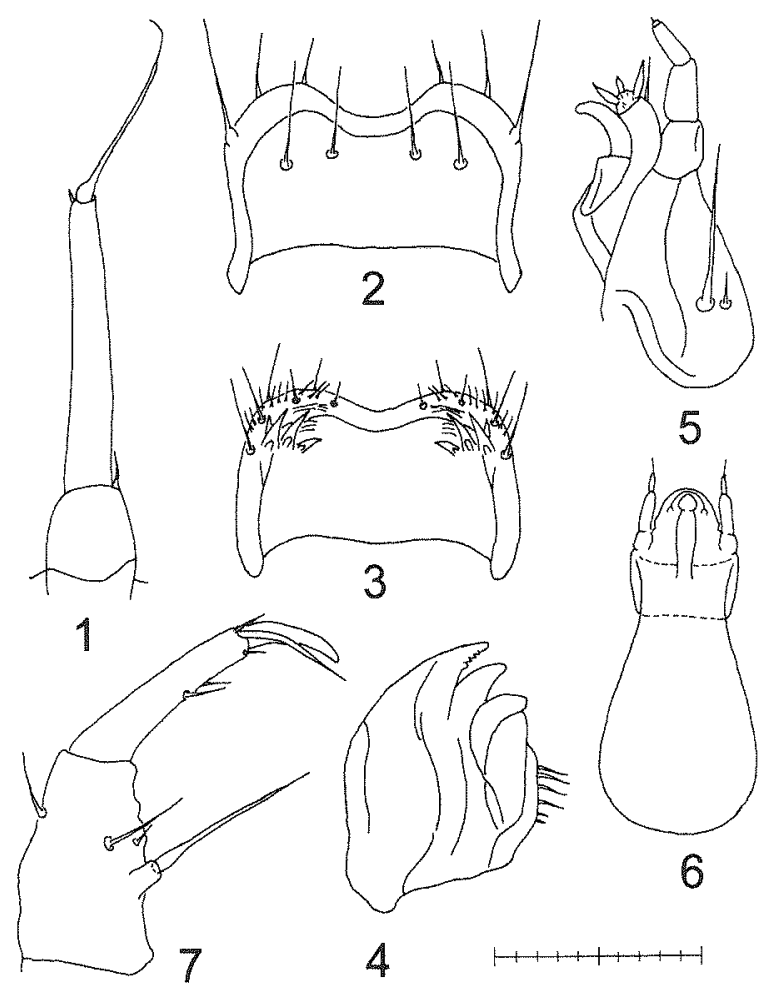

Figs 1-7: Micropterix aruncella, scale $0.1 \mathrm{~mm}$ (original drawings by B. KLAUSNITZER). 1 - antenna; 2 - labrum; 3 - epipharynx; 4 - right mandible, ventral; 5 - maxillary stipes, with palp and lobes, ventral; 6 - labium ventral; 7 - hind leg. 
and a single ventrolateral row. The ventrolateral bulge on the mesothorax and metathorax has a double-row with no small lateral hairs. The dorsal pair of rows lie more or less adjacent each other on the abdominal segments 1-5, on segment 6 they are slanting, and on the segments 7 and 8 they are almost one behind another. The dorsolateral rows are slanting on the mesothorax and metathorax to the $7 \mathrm{th}$ abdominal segment, while on the 8 th abdominal segment they are more or less one behind another.

The arrangement of the club-shaped hairs deviates on the prothorax and on the 9th abdominal segment. Dorsally, the prothorax has 2 transverse rows of club-shaped hairs, one frontally with 8 hairs, the other in the middle with 6 hairs. From above, 6 or 4 clubshaped hairs are visible, the hairs on the sides lie in a ventrolateral position. The more or less semicircular 9th abdominal segment has 4 club-shaped hairs visible from above on the distal edge, and on each side there are additionally 2 smaller, consecutive club-shaped hairs. The description by MARTYNOVA (1950) for Micropterix calthella differs slightly from that of LORENZ (1961) and our own observations in that she reports only one dorsolateral club-shaped hair on the 8th abdominal segment, only a single lateral or ventrolateral row and 6 club-shaped hairs on the 9 th abdominal segment.

Dorsally on each segment are three disc-like structures (a median unpaired, two smaller lateral) with a more or less honeycombed surface structure (Fig. 8), which is interpreted as insertion points for muscles. The median disc has a diameter of $0.15-0.18 \mathrm{~mm}$. KoZLOW (1991) points out the presence of centrally situated pores that are connected to tubes which extend into the body cavity. Also characteristic are the wrinkled and variously modified microsculptures of the body surface (star-shaped, comb-like, nipplelike, conical structures) (Figs 8-11, 16, 18), which HAMON \& CHAUVIN (1995) described in detail for Micropterix calthella. In this context it should be pointed out that the investigation of the integument in Sabatinca chalcophanes by KRISTENSEN (1990) reveals that the rather aberrant integument functions toward the maintenance of water balance during dry phases (a system of liquid-filled intracuticular cavities between the exocuticula and endocuticula; autapomorphy; after HAMON \& CHAUVIN 1995, similarly constructed in Micropterix calthella).

The stigmata are present (though they are very easily overlooked) and a tracheal system is present (HINTON 1958, HAMON \&. CHAUVIN 1995).

The body length of the $\mathrm{L}_{1}$ of Micropterix calthella is given as $0.8-0.9 \mathrm{~mm}$, the color is described as yellow-white; the body length of the larvae of the last stage is $5.3-5.6 \mathrm{~mm}$ (LORENZ 1961). According to HAMON \& CHAUVIN (1995) the body length of the $\mathrm{L}_{1}$ is $0.8 \mathrm{~mm}$, the width $0.2 \mathrm{~mm}$. The body length for the presumably final stage is $2.5 \mathrm{~mm}$ and the width $0.6 \mathrm{~mm}$. The body length of the last larval stage of Micropterix aruncella is $4.0-4.5 \mathrm{~mm}$.

The prognathous head can be fully retracted - up to the foremost edge of the mesothorax - into the prothorax, only the long antennae protrude forward which probably is their normal position during locomotion. The head capsule is long, cylindrical, oval, frontally somewhat tapered. Dorsally is a single hair in the middle of the frontoclypeus between the antennae. The epicranial suture and the adfrontal suture are not developed. On each side are 5 stemmata arranged in a circle ventral from the antennae. The shape of the head capsule deserves comments. LORENZ (1961) figured the Micropterix calthella head capsule as deeply indented in the posterior midline. I. HASENFUSS and N. P. KRISTENSEN (p. com.) have seen nothing of the kind in the Micropterix larvae they have 
examined - nor is such an indentation present in other described micropterigid larvae. They are confident that LORENZ (1961) was mistaken about the nature of the middorsal unmelanised cuticular thickening that occurs in exactly this position.

The antennae are long, approximately as long as the head capsule (autapomorphy of the Micropterigidae), and are composed of three segments (Fig. 1). The first segment is the broadest, but it is short, about as long as wide; the second segment is long, about seventimes as long as wide and somewhat thickened at the base; the third segment is also long and thin, over twenty-times as long as wide, but shorter than the second segment, its terminal bristle is shorter (for measurements, see Table 1) (in Micropterix calthella the third segment is short and ends with an apical, pointed bristle; LORENZ 1961). On the base of the second antennal segment is a short, slightly curved bristle. In some specimens a short bristle originates at the end of the lower third of the second antennal segment (perhaps it is the same bristle as mentioned before). A tiny bristle emerges from the base of the third antennal segment. The antennae emerge from clearly raised collars on the dorsal side of the head behind the edge of the clypeus (however, on the lateral side in all other Lepidoptera).

The frontoclypeal suture is faint. The labrum is detachable, and semicircular (Figs 2, $14)$, its frontal margin is narrowed in the middle, and the frontal and lateral edges are strongly sclerotized. The labrum is about $0.14 \mathrm{~mm}$ wide and on the sides about $0.09 \mathrm{~mm}$ long. On the upper side, 4 robust bristles form a row. On the frontal margin, 2 robust bristles emerge from each side of the lateral lobes, and one robust bristle from each lateral margin. On the underside (epipharynx), 4 conical structures are located laterally in the front corners. On the lateral lobes is a field of 10-15 bristles as well as a fringe of 6-8 fine bristles (Fig. 3). In Micropterix calthella, the middle section of the labrum is membranous (LORENZ 1961). This description also applies to the larvae investigated here if the edge is compared to the middle section. The labrum has 2 pairs of retractor muscles (all other Lepidoptera have but 1 pair).

The mandibles are weakly asymmetric, strongly sclerotized, tridentate, and the teeth are separated from each other by deep grooves extending almost to their bases. The cutting blade of the teeth are partly and weakly notched. The mandibles measure about 0.13 $\mathrm{mm}$ long and about $0.09 \mathrm{~mm}$ wide. A small tooth is situated dorsally and another ventrally in Micropterix calthella (after LORENZ 1961). Apically the inner edge of the mandibles is deeply notched. A fourth tooth is located on the outer side and is clearly set off. Toward the base is an internal row of 6-7 bristles (Fig. 4) (this feature may be of taxonomic value for distinguishing the species).

The cardo is set transverse, the stipes is oblong (length ca. $0.10 \mathrm{~mm}$; width ca. 0.07 $\mathrm{mm}$ ), externally with one long, curved bristle (length ca. $0.07 \mathrm{~mm}$ ) which extends to the first segment of the maxillary palpus (Fig. 5). Next to it is a short bristle (length ca. 0.01 $\mathrm{mm}$ ). The maxillae are composed of a definite galea and lacinia (unique plesiomorphy for the Lepidoptera; KRISTENSEN 1999). The laciniae are curved semicircularily, distally blunt, strongly sclerotized, and larger than the galea, which is only slightly sclerotized. On the rounded off end are 2 (3) strong and conical bristles and one (2) conical structures, which are perhaps bristles or sensillae. The maxillary palpus has three segments; the first and second are short and wide, 1.5 to twice as long as wide. Note that the basal "segment" of what LORENZ (1961) labelled the maxillary palp surely includes what HINTON (1958) termed the dististipes, which apparently is a composite formation. The first 
segment is almost linear, the second is slightly conical; the third is likewise short, tapers at the tip, and is more than three times as long as wide (for measurements, see Table 2). On the third segment is an area about $0.006 \mathrm{~mm}$ wide with numerous sensillae that are about $0.003 \mathrm{~mm}$ tall, jutting out amongst them is a peg-like sensillum (length ca. $0.007 \mathrm{~mm}$ ). In
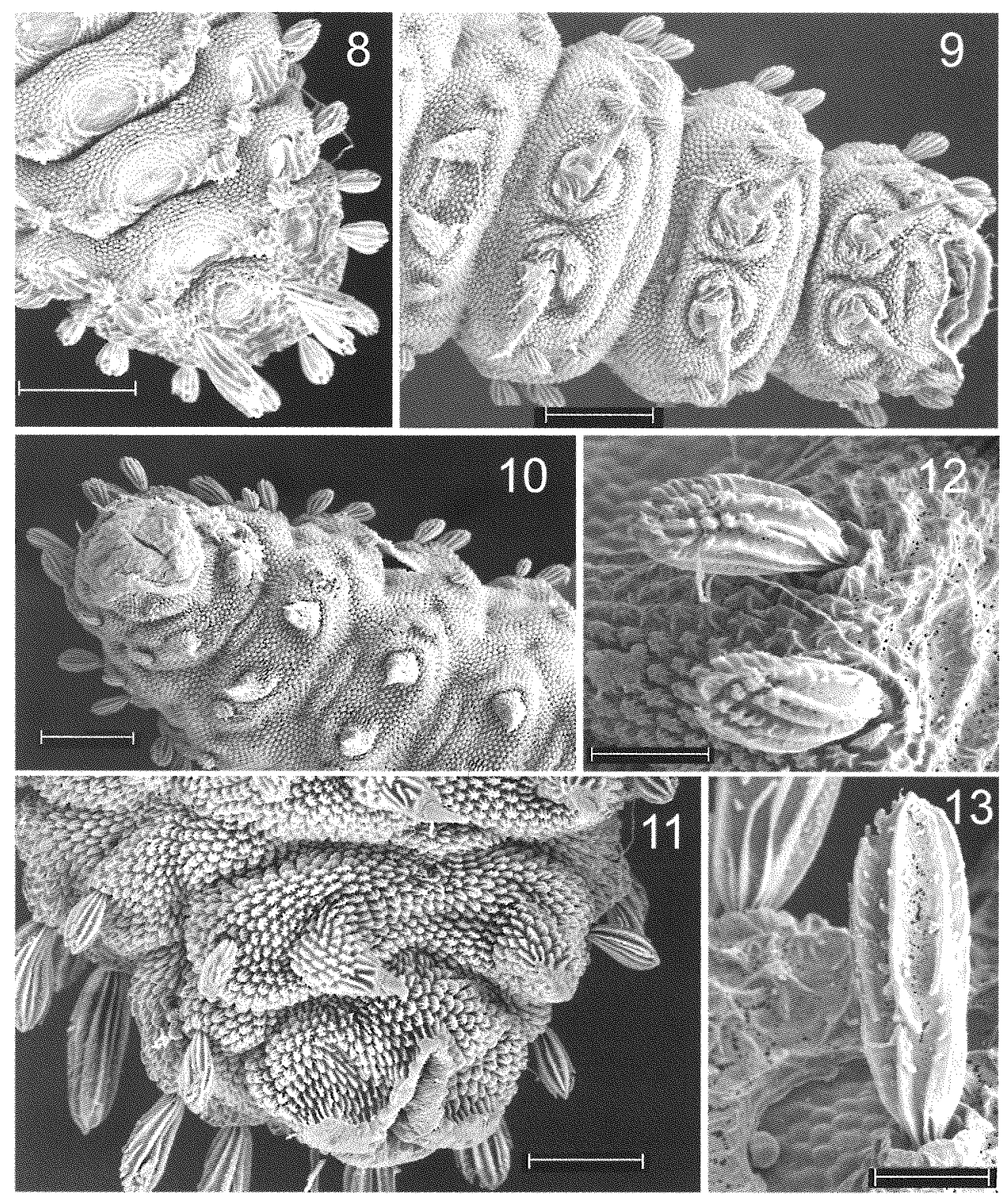

Figs 8-13: Micropterix aruncella, (SEM-photographs by G. EISENBEIS): 8 - Abdominal segments 6-9, dorsal, scale $200 \mu \mathrm{m} ; 9$ - Thorax, 1 st abdominal segment, ventral, scale $200 \mu \mathrm{m} ; 10$ - Abdominal apex, ventral, scale $200 \mu \mathrm{m} ; 11$ - Abdominal apex, diagonal, scale $100 \mu \mathrm{m} ; 12$ - Abdominal segment, club-shaped hairs, dorsal, scale $50 \mu \mathrm{m} ; 13$ - Abdominal apex, club-shaped hair, scale $50 \mu \mathrm{m}$. 
Micropterix calthella the second segment is the longest, much thinner than the first and somewhat narrowed in the middle (LORENZ 1961).

The labium consists of a weakly sclerotized mentum and the submentum is indistinctly set apart (Figs 6, 15), widest at its base and narrowing toward the prementum (length about $0.1 \mathrm{~mm}$; width at the base ca. $0.08 \mathrm{~mm}$ ). The prementum is somewhat wider than long (width $0.05 \mathrm{~mm}$; length $0.03 \mathrm{~mm}$ ), and the prementum truncated anteriorly. The palpiger (or basal segment) emerges laterally, proximally following a lateral wall of, which

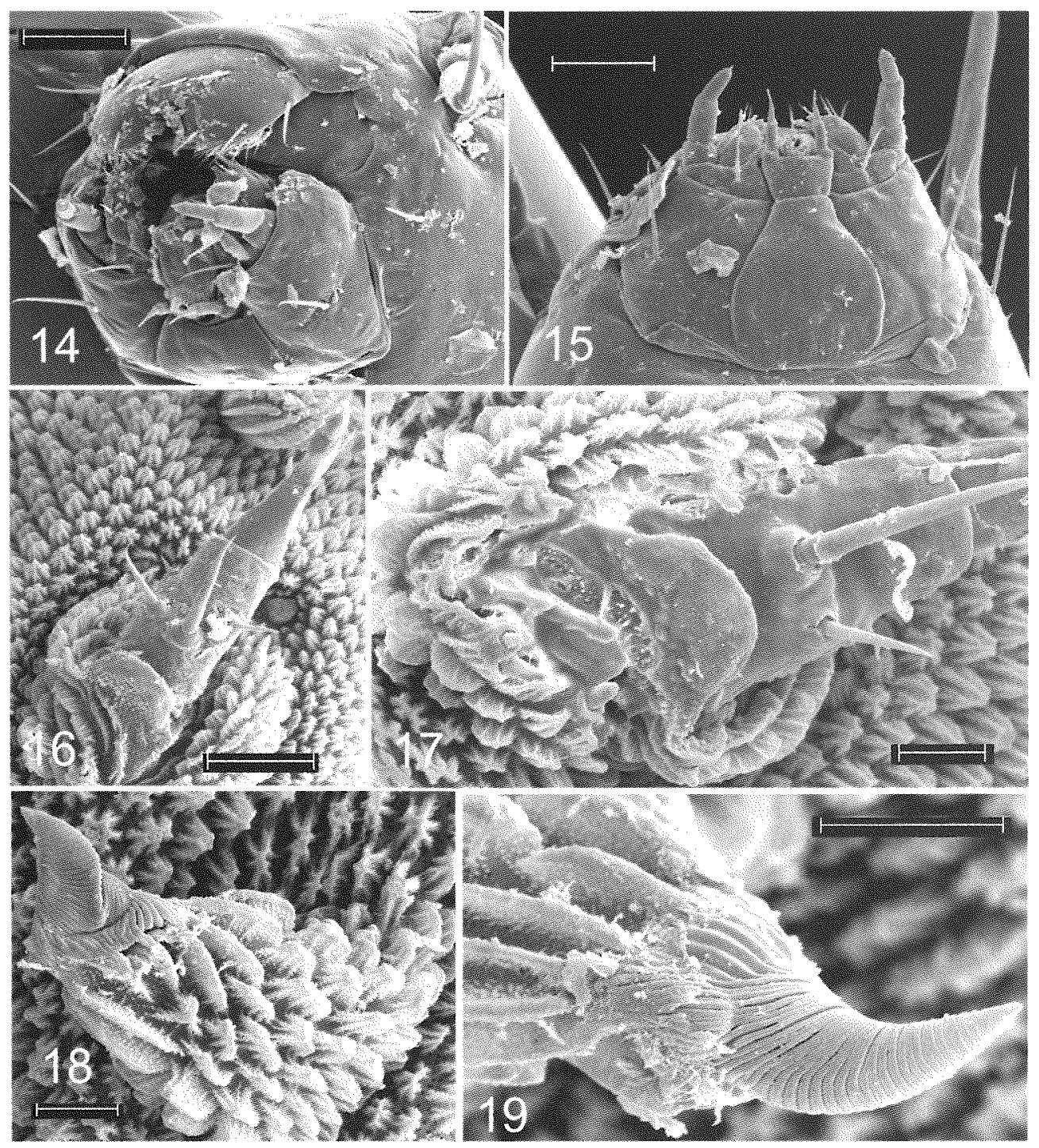

Figs 14-19: Micropterix aruncella, (SEM-photographs by G. EISENBEIS): 14 - Head, diagonal from the front, scale $50 \mu \mathrm{m}) ; 15$ - Maxillae, labium, ventral, scale $50 \mu \mathrm{m} ; 16$ - Thoracic leg, ventral, scale $50 \mu \mathrm{m} ; 17$. Thoracic leg, base, ventral, scale $20 \mu \mathrm{m} ; 18$ - 2nd Abdominal segment, abdominal proleg, scale $20 \mu \mathrm{m} ; 19$ 8th Abdominal segment, abdominal proleg, scale $20 \mu \mathrm{m}$. 
is long, strongly sclerotized and extends over the entire length of the prementum. The labial palpi are two-segmented and slender; the first segment is about three times as long as wide, the second segment is about five times as long as wide and distally ends with a terminal bristle, which is about as long as the second segment (for measurements, see Table 3).

Spinneret is absent. Between the labial palpi is an unpaired tubular structure that obviously encloses a cavity with an opening in the front. The labial gland orifice is situated in an apical furrow on the lower wall of the premento-hypopharyngeal lobe. On the front margin of the prementum is a semicircular area of uncertain origin with 2 sensilla. The prothorax is frontally enlarged and envelopes the head capsule like a ring (Fig. 9). The $L_{1}$ have characteristic bristles; according to MARTYNOVA (1950) they are absent in the last larval stage (KOZLOW 1991). According to HAMON \& CHAUVIN (1995) the bristles are asymmetrical and contain 20-30 digitate projections (and are present only on the prothorax).

The thoracic legs appear to be three-segmented (Figs 7, 16, 17). CHAPMAN (1894) and MARTYNOVA (1950) also came to this conclusion. DAVIS (1987) however regarded the legs as composed of four segments (including the pretarsus): the coxa is reduced, while the trochanter + femur (or tibia + tarsus) are united together. This fusion was also recognized by KOZLOW (1991). A different interpretation was offered by SCOBLE (1992), who regarded the coxa + trochanter + femur as a single unit. A decisive judgment cannot yet be submitted, detailed examinations would first be necessary. The variant, coxa trochanter + femur - tibia + tarsus, is certainly very likely since the bristles are located on the points of fusion (KRISTENSEN \& NIELSEN 1983).

The segment composed of the trochanter + femur is strongly sclerotized, conical, 1.62.2 times as long as wide, on the inside with a long $(0.08 \mathrm{~mm})$ bristle on an elevated base $(0.01 \mathrm{~mm}$ high). Immediately adjacent to it is a shorter, slightly curved bristle, and distally are 2 more short bristles (distally in Micropterix calthella is a single long bristle; LORENZ 1961). The second segment (tibia + tarsus) is clearly sclerotized, slender, 4.5-6 times as long as wide, narrow in the middle and distally tapering. Distal to the middle are 2 adjacent bristles and two further bristles are situated near the end of this leg segment. The claws are scythe-shaped, about 0.4- 0.5 times long as the tibia + tarsus is wide. Near the base of the claws is a bristle with a thickened base, from its middle to the apex it is slightly curved and tapering; the apex of this bristle is somewhat broadened. The bristle extends almost to the tip of the claw. Just before the tip is another short, curved bristle, which does not exceed the apex (for measurements, see Table 4). In Micropterix calthella is a thin claw with a terminal bristle (LORENZ 1961).

Abdominal segments 1-8 have abdominal prolegs that contain no musculature (HINTON 1946, 1958) and the crochets, which are present in all Lepidoptera, are absent (autapomorphy; according to SCHELLAUF 1993) (Fig. 10). „The un-musculated and pointed abdominal prolegs are indeed very likely an autapomorphy of Micropterix (and perhaps a few other micropterigid genera). But the absence of proleg muscles or proleg crochets is not apomorphic at the basal lepidopteran level. Typical caterpillar prolegs with intrinsic muscles and with apical crochets may be a groundplan autapomorphy of the Neolepidoptera, a clade that arose in the seventh splitting event discernible within the extant Lepidoptera. They are first encountered in the Exoporia which arose in the 
eighth splitting event (KRISTENSEN 1997), but may, of course, be present already in neopseutid or even lophocoronid larvae that remain unknown" (KRISTENSEN, p. com.) The abdominal prolegs are broad and rounded at the base and covered with a rib-like microsculpture (Figs 18,19). The prolegs are conical and bend toward a clear, almost transparent apical section, which is more or less distinct and from which the nearly transparent, curved "claw" emerges (if it is the claw) (Figs 18, 19). In Micropterix calthella the proleg terminates with a bristle, according to LORENZ (1961), however this was mentioned neither by CHAPMAN (1894) nor MARTYNOVA (1950). The surface of the "claw" is coated with 35-40 concentric rings (the illustrations in CHAPMAN 1894 and MARTYNOVA 1950 indicate the presence of fewer rings in Micropterix calthella). The total length of the abdominal prolegs in larvae of the last stage is about $0.15 \mathrm{~mm}$ (sclerotized section: $0.10 \mathrm{~mm}$, length of „claw": 0.03-0.04 mm).

The 9th abdominal segment turns steeply downward at its apex. The 10th abdominal segment forms a prominent, three-lobed anal outgrowth (,sucker") (Figs 10, 11), which plays a role not only in locomotion but also in molting (in this area other Lepidoptera have a pair of terminal pseudopods). Caudal from the "sucker" are 2 simple bristles with a length of $0.09 \mathrm{~mm}$ each. Molting occurs differently from the other Lepidoptera, since the larvae, according to LORENZ $(1959,1961)$, attach themselves with help of the „sucker“ and conduct the molting process while standing virtually straight up or at an angle.

\section{Head capsule width of larval stages}

A total of 158 larvae of Micropterix aruncella were extracted from the soil samples between May 29 and October 17, 1998. The relatively large number of larvae found at different developmental stages offered the possibility to analyze the age structure and to estimate the life cycle. In order to measure the head capsule width of the instars, it had to be pulled out to the anterior margin of the mesothorax. The measurements were made using an excavated slide.

DYAR's rule states that the head capsule width of insect larvae increases by a speciesspecific factor (within the range of 1.2-1.7) for each molt. If the head capsule dimensions are known for, at least, two larval stages, then the number and the size of the further stages can be derived. Fig. 20 shows the frequency distribution of the head capsule widths in Micropterix larvae. The values lie between $0.09 \mathrm{~mm}$ and $0.33 \mathrm{~mm}$. The values for the apparent last larval stage range from 0.25 to $0.33 \mathrm{~mm}$, the average value (weighted average of head capsule width and the respective frequency of the measured value) of the head capsule width in this stage lies at $0.29 \mathrm{~mm}$. The frequency distribution of the head capsule width of the younger larvae shows two easily recognizable maxima and between them a frequency minimum of $0.18 \mathrm{~mm}$. The weighted average of the head capsule width of the larval stages which had values between $0.18-0.23$ amounts to $0.21 \mathrm{~mm}$. From this a growth factor of 1.38 is calculated for the larval stage preceding the final stage. Using this factor, the average head capsule width for the preceding stage is calculated at $0.15 \mathrm{~mm}$. This conforms to actual results, as seen in Fig. 20. If one divides 0.15 by the factor 1.38 , the result is a head capsule width for the preceding, smaller larval stage of $0.11 \mathrm{~mm}$. In reality, seven larvae were recorded with measurements between 0.09 and $0.11 \mathrm{~mm}$. 
It follows from the analysis of the frequency distribution of the head capsule widths, that Micropterix aruncella should develop with a growth factor of 1.38 for four larval stages. The average head capsule widths of the $\mathrm{L}_{1}$ to $\mathrm{L}_{4}$ stages amount to $0.11 ; 0.15 ; 0.21$ und $0.29 \mathrm{~mm}$, respectively.

Fig. 20: Frequency distribution of head capsule widths ( $\mathrm{mm}$ ) of Micropterix aruncella larvae extracted from soil and litter samples in alpine pasture land near the treeline above Neustift in the Stubai Valley (1.860-2.150 m a.s.l.).

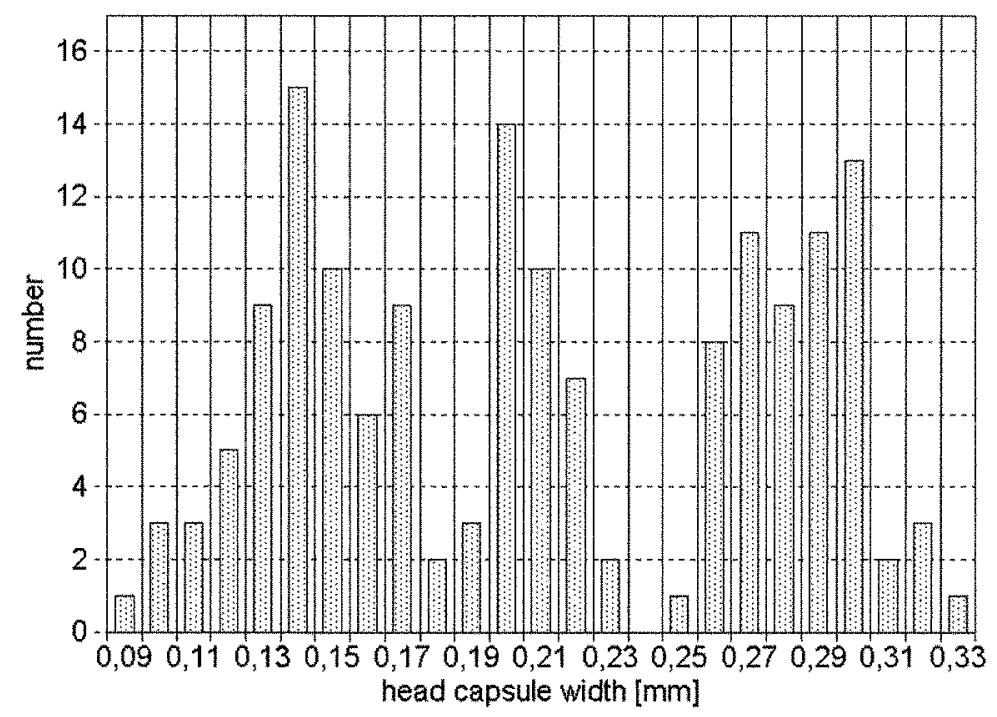

Tab. 1: Size of the antennal segments of the larvae in the last stage of Micropterix aruncella. [Average values in $\mathrm{mm}$.

\begin{tabular}{|l|l|}
\hline 1st Antennal segment, length & 0.04 \\
\hline 1st Antennal segment, width & 0.04 \\
\hline 2nd Antennal segment, length & 0.14 \\
\hline 2nd Antennal segment, width & 0.02 \\
\hline 3rd Antennal segment, length & 0.07 \\
\hline 3rd Antennal segment, width & 0.003 \\
\hline $\begin{array}{l}\text { 3rd Antennal segment, terminal bristle, } \\
\text { length }\end{array}$ & 0.03 \\
\hline
\end{tabular}


Tab. 2: Size of the segments of the maxillary palpus in the larvae of the last stage of Micropterix aruncella. [Average values in $\mathrm{mm}$ ].

\begin{tabular}{|l|l|}
\hline 1st Segment, length & 0.03 \\
\hline 1st Segment, width, maximal & 0.02 \\
\hline 2nd Segment, length & 0.03 \\
\hline 2nd Segment, width, maximal & 0.015 \\
\hline 3rd Segment, length & 0.025 \\
\hline 3rd Segment, width, maximal & 0.008 \\
\hline
\end{tabular}

Tab. 3: Size of the segments of the labial palpus in the larvae of the last stage of Micropterix aruncella. [Average values in $\mathrm{mm}$ ].

\begin{tabular}{|l|l|}
\hline 1st Segment, length & 0.02 \\
\hline 1st Segment, width & 0.006 \\
\hline 2nd Segment, length & 0.01 \\
\hline 2nd Segment, width & 0.002 \\
\hline Terminal bristle & 0.012 \\
\hline
\end{tabular}

Tab. 4: Measurement of the segments of the thoracic leg (maximal length and width) of Micropterix aruncella larvae in the last stage. [Averages in $\mathrm{mm}$ ].

\begin{tabular}{|l|l|l|l|}
\hline & Foreleg & Midleg & Hind leg \\
\hline Trochanter + Femur & $0.08 / 0.05$ & $0.11 / 0.05$ & $0.10 / 0.06$ \\
\hline Tibia + Tarsus & $0.09 / 0.02$ & $0.12 / 0.02$ & $0.10 / 0.02$ \\
\hline Claw & $0.04 / 0.01$ & $0.05 / 0.01$ & $0.05 / 0.01$ \\
\hline
\end{tabular}

Tab. 5: Differences between the last-instar larvae of Micropterix armullla, Micropterix calthella and Micropterix aureatella (values according to CARTER \& DUGDALE 1982).

\begin{tabular}{|l|l|l|l|}
\hline & $\begin{array}{l}\text { aruncella (SCOPOL, } \\
1763)\end{array}$ & $\begin{array}{l}\text { calthella (LINNÉ, } \\
1761)\end{array}$ & $\begin{array}{l}\text { aureatella (ScopoLI, } \\
1763)\end{array}$ \\
\hline Body length & $2.7 \mathrm{~mm}$ & $4.5 \mathrm{~mm}$ & not given \\
\hline Body form & elongate & cylindrical & not given \\
\hline Body color & white-gray & dark gray & yellow-white \\
\hline
\end{tabular}


Tab. 6: Population densities (ind. $/ \mathrm{m}^{2}$, the year's average values) of Micropterix aruncella larvae at selected sites on alpine pasture land near the treeline. Two separate soil samples, each with a $30 \mathrm{~cm}$ diameter, were taken on five dates in 1998 at each site, except that no probes were taken at the fallow site on the first collection date.

\begin{tabular}{|c|c|c|c|c|c|c|}
\hline Site & May 29 & July 3 & Aug. 10 & Sept. 10 & Oct. 17 & Average \\
\hline Fallow & - & 49.5 & 49.5 & 127.3 & 49.5 & 55.2 \\
\hline Reforested & 127.3 & 56.6 & 49.5 & 49.5 & 28.3 & 62.2 \\
\hline $\begin{array}{c}\text { Abandoned } \\
\text { pasture }\end{array}$ & 0 & 29.07 & 99.0 & 169.8 & 452.7 & 203.7 \\
\hline $\begin{array}{c}\text { Lightly grazed } \\
\text { Pasture }\end{array}$ & 0 & 14.1 & 0 & 14.1 & 0 & 5.7 \\
\hline $\begin{array}{c}\text { Intensively } \\
\text { grazed Pasture }\end{array}$ & 0 & 7.0 & 0 & 0 & 0 & 1.4 \\
\hline Meadow & 0 & 0 & 0 & 0 & 14.1 & 2.8 \\
\hline
\end{tabular}

\section{Discussion}

The larvae of the Micropterigidae are distinguishable from those of other Lepidoptera in several conspicuous features (antennae longer than head capsule; head capsule entirely retractable into the thorax; abdominal segments 1-8 with acute abdominal prolegs lacking crochets; body with several rows of flattened, ribbed, club-shaped hairs; body hexagonal in cross-section). Based on these characters, determination keys usually contrast all other families against them (GERASIMOV 1937, CARTER \& KRISTENSEN 1999). Presumably, the oldest detailed description and illustration of the $\mathrm{L}_{1}$ of Micropterix calthella is that of CHAPMAN (1894, Fig. 3, P1. 6). Both GERASIMOV (1937) and PORTIER (1949) attribute authorship to CHAPMAN (1894), who named the larvae Ericocephala calthella, described its important characteristics (body form, antennae, abdominal prolegs, retracted head, dorsal discs, club-shaped hairs) and provided illustrations of the habitus of $L_{1}$ as well as of the antennae, abdominal prolegs, thoracic legs, the abdominal apex and the clubshaped hairs. His publication of 1916/1917 included photographs of the habitus, the head capsule and various external details of the integument.

Various authors have pointed out means to distinguish the larvae of the different species of the genus Micropterix. CARTER \& DUGDALE (1982) describe the larvae of Micropterix aureatella (SCOPOLI, 1763) as "characteristically yellow-white“ and claim that the species they investigated can be separated according to the size of the last larval stage, its form and colour (Tab. 5). They also mentioned differences in the structure of the head between Micropterix aruncella and Micropterix calthella, making reference to the illustrations of LORENZ (1961), unfortunately however without specifying these differences. Likewise, LUFF (1964) mentioned the larvae of Micropterix aruncella, yet did not provide distinguishing characteristics. CHAPMAN (1916/1917) furnished a photograph of the abdominal apex of a larva of Micropterix allionella (FABRICIUS, 1794), however it does do not enable visible distinction from the allied species Micropterix calthella. Finally, LORENZ (1961) described the larvae of Micropterix calthella and listed several means for differentiating it from Micropterix aruncella. 


\section{Acknowledgements}

We thank Dr. R. Gaedike, Eberswalde, Deutsches Entomologisches Institut, Prof. Dr. N. P. Kristensen, Copenhagen, Zoologisk Museum, and Dr. H. Steuer, Bad Blankenburg, who provided literature on the larvae of the Micropterigidae. This applies also to M. Gerstberger, Berlin, who contributed valuable comments and advise. Fruitful comments on drafts of the paper by Prof. Dr. N. P. Kristensen are gratefully acknowledged. The identification of the freshly emerged moths was provided by Dr. P. Huemer, Innsbruck, Naturwissenschaftliche Sammlungen des Tiroler Landesmuseum Ferdinandeum. Measurement of the head capsules was conducted by Dr. Sieglinde Meyer, Innsbruck. To these persons we extend our sincete gratitude. In addition, we thank John Plant (Vienna) who rendered the paper into English.

\section{References}

CARTER, D. J. \& DUGDALE, J. S. 1982: Notes on collecting and rearing Micropterix (Lepidoptera: Micropterigidae) larvae in England. - Entomol. Gazette 33: 43-47.

CARTER, D. J. \& KRISTENSEN, N. P. 1999: 3. Classification and Keys to Higher Taxa. - In: KRISTENSEN, N. P.: Lepidoptera, Moths and Butterflies 1. Handbuch der Zoologie: 27-40. - Berlin \& New York.

CHAPMAN, T. A. 1894: Some notes on the Micro-Lepidoptera whose larvae are external feeders, and chiefly on the early stages of Eriocepbala calthella (Zygaenidac, Limacodidae, Eriocephalidae). - Trans. R. ent. Soc. London 1894: 335-350, pl. 6, 7 .

CFAPNLAN, T. A. 1916/1917: Mirropteryx entitled to ordinal rank; Order Zeugloptera. - Trans. R. ent. Soc. London 1916: 310-314, pl. 81-92.

DAVIS, D. R. 1987: Micropterigidae (Micropterigoidea). - In: STEHR, F. W.: Immature Insects. Volume 1:341 343. - Kendall, Iowa.

GAEDIKE, R. \& HEINICKE, W. (Hrsg.) 1999: Entomofauna Germanica 3. Verzeichnis der Schmetterlinge Deutschlands. - Ent. Nachr. Ber. Beiheft 5: 1-216. Dresden.

GERASN FOT, A. 1937: Bestimmungstabelle der Familien von Schmetterlingsraupen, - Stettin. ent. Ztg. 98: 281-300.

HAMON, C. \& CHAUVIN, G. 1995: Larval integument and its differentiations in Micropterix calthellad. L. (Lepidoptera: Micropterigidae): anatomy and ultrastructure, - Int. J. Insect Morphol. \& Embryol. 24: 213-222.

HANnemann, H. J. 1957: Bemerkungen über die Zucht von Micropterix calthella L. (Lep.) - Mitt. Dtsch. Ent. Ges. 16: 31 .

HASHINOTO, S. 2001: Larval chaetotaxy of the genera Paramartyria and Neomicropteryx in Japan (Lepidoptera: Micropterigidae). - Japanese Journal of Systematic Entomology 7: 255-264.

HEATH, J. 1976: Micropterigidae. - In: HEATH, J. (ed.): The moths and butterflies of Great Britain and Ireland. Vol. 1: Micropterigidae - Heliozelidae. - London, 343 S.

HEATH, J. 1996: Micropterigoidea, - In: KARSHOLT, O. \& RAZOWSKI, J: The lepidoptera of Europe. - Stenstrup.

HINTON, H. E. 1946: On the homology and nomenclature of the setae of lepidopterous larvae, with some notes on the phylogeny of the Lepidoptera. - Trans. R. ent. Soc. London 97: 1-37.

Hinton, H. E. 1958: The phylogeny of the Panorpoid ordets. - Ann. Rev. Ent. 5/3: 181-206.

Huemer, P. \& TARMANN, G. 1993: Die Schmetterlinge Österreichs (Lepidoptera). - Tiroler Landesmuseum. Ferdinandeum, Innsbruck, Beilageband 5, 224 pp.

KozLow, M. W. 1991: Die Grundplanmerkmale und Autapomorphien im Bau der Micropterigiden- Raupen (Lepidoptera). - Verh. XII. Int. Symp. Entomofaunistik Mitteleuropas (SIEEC), Kiew 1988: 326-330.

KRISTENSEN, N. P. 1990: The trunk integument of Zeuglopteran larvae: one of the most aberrant arthropod cuticles known (Insecta, Lepidoptera). - Bull. Sugadaira Montane Res. Cent. 11: 101-102.

KRISTENSEN, N. P. 1997: Early Evolution of the Lepidoptera + Trichoptera Lineage: Phylogeny and the Ecological Scenario. - In: GRANDCOLAS, P. (ed.), The Origin of Biodiversity in Insects: Phylogenetic Tests of Evolutionary Scenarios, - Mém. Mus. natn. Hist. nat. 173: 253-271.

Kristensen, N. P. 1999: 4. The Non-Glossatan Moths. - In: Kristensen, N. P., Lepidopterd: Moths and Butterflies 1. Handbuch der Zoologie: 41-49. - Berlin \& New York. 
KRISTENSEN, N. P. \& NIEISEN, E. S. 1983: The Heterobathmia life history elucidated: Immature stages contradict assignment to suborder Zeugloptera (Insecta, Lepidoptera). - Z. zool. Syst. Evol. Forsch. 21: 101-124.

LORENZ, R. E. 1959: Vorläufiger Bericht über meine Zuchtversuche mit Micropterix calthella L. (Lep., Micropterygidae). - Mitt. Dtsch. Ent. Ges. 18: 42-45.

LORENZ, R. E. 1961: Biologie und Morphologie von Micropterix calthella (L.) (Lep., Micropterygidae). - Dtsch. ent. Z. N. F. 8: 1-23.

LufF, M. L. 1964: Larvae of Micropterix (Lepidoptera: Micropterigidae). - Proc. ordinary Meeting, Held on 4th March 1964. - Proc. R. ent. Soc. London 29: 6.

MARTYNOVA, E. F. 1950: Über die Beschaffenheit der Raupen der Micropteryx HBN. - Rev. Ent. [Ent. Obozr.] 31: 142-150. (in Russian)

MEYER, E. 1980: Ökologische Untersuchungen an Wirbellosen des zentralalpinen Hochgebirges (Obergurgl, Tirol), IV: Aktivitätsdichte, Abundanz und Biomasse der Makrofauna. - Veröff. Univ. Innsbruck 125: 1-53.

MEYER, E.; KÖSSLER, W. \& KLAUSNITZER, B. 2002: Zur Kenntnis der Biologie und Ökologie von Micropterix aruncella (SCOPOL) an der zentralalpinen Waldgrenze (Lep., Micropterigidae). - Ent. Nachr. Ber. 46: 17-22.

PARENT, U. 1965: La larva neonata di Micropteryx calthella ed il suo metodo di allevamento. - Mem. Soc. ent. Ital. 44: 23-25.

PORTIER, P. 1949: La Biologie des Lépidoptčres. - Enc. ent., Lechevalier, Paris.

SCHELLAUF, H. 1993: Zur Funktionsmotphologie und Phylogenie der larvalen Abdominalbeine primitiver Lepidopteren. - Mitt. Dtsch. Ges. allg, angew. Ent. 8: 463-466.

SCOBLE, M. J. 1992: The Lepidoptera: Form, Function and Diversity. - The Natural History Museum, Oxford University Press, Oxford, $352 \mathrm{~S}$.

TILlyard, R. J. 1922/1923: On the Larva and Pupa of the Genus Sabatinca (Order Lepidoptera, Family Micropterygidae). - Proc. R. ent. Soc. London 1922: 437-453.

TUSKES, P. M. \& SMTTH, N. J. 1984: The life history and behavior of Epimartyria pardella (Micropterigidae). - J. Lepid. Soc. 38: 40-46.

YASUDA, T. 1962: On the larva and pupa of Neomicropteryx nipponensis ISSIKI with its biological notes (Lepidoptera, Micropterigidae). - Kontyu 30: 130-136.

\section{Author's addresses:}

Prof. Dr. BERNHARD KLAUSNITZER

Lannerstrasse 5

D-01219 Dresden

Germany

e-mail: klausnitzer.col@t-online.de

Prof. Dr. ERWIN MEYeR and Dipl.-Biol. WOLFGANG KÖSSLER

Institut für Zoologie und Limnologie

der Universität Innsbruck

Technikerstrasse 25

A-6020 Innsbruck, Austria

e-mail: Erwin.Meyer@uibk.ac.at

Prof. Dr. GeRHARD EISENBEIS

Fachbereich Biologie, Institut für Zoologie

der J.-Gutenberg-Universität Mainz

D-55099 Mainz

Germany 